\title{
Factors associated with co-occurrence of large carnivores in a human-dominated landscape
}

\author{
Babu Ram Lamichhane ${ }^{1,2,3}$ (D) Herwig Leirs ${ }^{2} \cdot$ Gerard A. Persoon ${ }^{1} \cdot$ Naresh Subedi $^{3}$. \\ Maheshwar Dhakal $^{4}$ - Bishwa Nath Oli ${ }^{4}$. Simon Reynaert ${ }^{2} \cdot$ Vincent Sluydts $^{2}$. \\ Chiranjibi Prasad Pokheral ${ }^{3}$. Laxman Prasad Poudyal ${ }^{6}$. Sabita Malla ${ }^{7}$. \\ Hans H. de longh ${ }^{2,5}$
}

Received: 29 August 2018 / Revised: 15 February 2019 / Accepted: 11 March 2019 /

Published online: 18 March 2019

(c) The Author(s) 2019

\begin{abstract}
We investigated the factors facilitating co-occurrence of two large carnivores, tigers (Panthera tigris) and common leopards (Panthera pardus), within a human-dominated landscape. We estimated their density and population size using camera-trap photographs and examined spatial segregation of habitats, temporal activity pattern, and diets in Chitwan National Park, Nepal. A Bayesian spatially-explicit capture-recapture model estimated densities of 3.2-4.6 (3.94 \pm 0.37$)$ tigers and 2.6-4.1 $(3.31 \pm 0.4)$ leopards per $100 \mathrm{~km}^{2}$ with abundance of 70-102 tigers and 66-105 leopards. Tigers occupied the prime habitats (grasslands and riverine forests) in alluvial floodplains of the Park whereas leopards appeared in Sal forests and marginal areas where livestock are present. Both tigers and leopards showed crepuscular activity patterns with a high overlap but tigers were less active during the day compared to leopards. Leopards' activity in the day increased in the presence of tigers. Tiger and leopard diet overlapped considerably (90\%). Compared to leopards, tigers consumed a higher proportion of the large prey and a smaller proportion of livestock. Our study demonstrates that sympatric large carnivores can coexist in high densities in prey rich areas that contain a mosaics of habitats. To increase the resilience and size of the Chitwan carnivore population, strategies are needed to increase prey biomass and prevent livestock depredation in adjacent forests. Long-term monitoring is also required to obtain a detailed understanding of the interaction between the large carnivores and their effects on local communities living in forest fringes within the landscape.
\end{abstract}

Keywords Tiger (Panthera tigris) · Common leopard (Panthera pardus) · Abundance and density $\cdot$ Diet $\cdot$ Activity pattern $\cdot$ Chitwan National Park (Nepal)

Communicated by David Hawksworth.

Electronic supplementary material The online version of this article (https://doi.org/10.1007/s1053 1-019-01737-4) contains supplementary material, which is available to authorized users.

Babu Ram Lamichhane

baburaml@gmail.com

Extended author information available on the last page of the article 


\section{Introduction}

Large carnivores have a relatively greater influence on the community structure through resource facilitation and trophic cascades, although they remain in low densities naturally due to energetic constraints (Ripple et al. 2014; Schmitz et al. 2000). They are threatened globally by habitat fragmentation and loss, poaching and illegal trade for their body parts, declining prey and conflict with humans (Karanth and Chellam 2009). Because survival of large carnivores is conservation dependent in increasingly human-dominated landscapes (Weber and Rabinowitz 1996; Linnell et al. 2001; Wikramanayake et al. 2004), conservation strategies should focus on the protection of core breeding areas (or source sites) which have the potential to repopulate neighboring areas when embedded in larger landscapes (Kenney et al. 2014). The Terai Arc Landscape (TAL) in Nepal and India is one of such landscapes for conservation of large mammals including top-predators tigers and common leopards (hereafter called 'leopards') (Chanchani et al. 2014).

Tigers and leopards are the two largest sympatric felids in Asian forests for a long time (Simcharoen et al. 2014; Goodrich et al. 2015; Jacobson et al. 2016; Stein et al. 2018). Paleontological and molecular studies suggest leopards evolved in Africa and dispersed to Asia ca. 2 million years ago whereas tigers are endemic to Asia; they appear in the fossil record ca. 1.5 million years ago (Turner and Anton 1997; Lovari et al. 2015). Both are obligate meat-eaters and solitary hunters. However, they differ in body size; an adult tiger $(65-306 \mathrm{~kg})$ is approximately four times the body weight of adult leopard (28-90 kg) (Seidensticker 1976).

Interference and inter-guild competition of large carnivores resulting in the displacement of the subordinate by dominant is common (Holt and Polis 1997; Linnell and Strand 2000). Such competition by tigers (dominant) towards leopards (sub-ordinate) has been widely observed (Odden et al. 2010; Harihar et al. 2011). However, Karanth and Sunquist (2000) found high dietary overlap in India and Simcharoen et al. (2018) found both dietary and spatial overlap in Southeast Asia with no evidence of displacement. High dietary and spatial overlap suggests that both interference and resource competition may occur (Simcharoen et al. 2018; Lovari et al. 2015). Ultimately, prey composition and density as well as habitat types play a key role in determining the nature of tiger-leopard interactions (Carter et al. 2015).

Lovari et al. (2015) reported a large overlap in tiger and leopard diet in the western part of TAL indicating no prey partitioning. They suggested additional research was needed to examine if spatial and/or temporal partitioning occurs between these large cats. We selected Chitwan National Park (CNP) situated in the eastern part of TAL for this study to examine the factors facilitating the co-occurrence of these large carnivores. CNP holds one of the largest populations of tigers and leopards in TAL (Thapa 2011; Karki et al. 2015). Tigers and leopard co-occur in CNP with a large overlap in their home ranges (Seidensticker 1976). Co-occurrence could be facilitated by high prey biomass, diversity of prey sizes and dense vegetation that may reduce tiger leopard encounter rate (Bhattarai and Kindlmann 2012a; Simcharoen et al. 2018). However, McDougal (1998) recorded intra-guild predation of at least five leopards by tigers in less than 2 years in the western part of CNP when the tiger population was recovering there. Since the tiger density has increased in CNP, the impact on the spatial dynamics of leopards remains unknown. Given the relatively small size of CNP and the adjoining forests in the human-dominated landscape, an understanding of these competitive dynamics is critical to ensure conservation of both tigers and leopards. Although tigers are relatively well studied in CNP (Sunquist 1981; Smith and McDougal 
1991; Smith 1993; McDougal et al. 2016), few studies have been conducted on leopards (Thapa 2011). Establishing baseline ecological, behavioral and demographic data is also important for future management strategies.

This study examined how two sympatric large carnivores, tigers and leopards, co-occur in CNP, a global biodiversity hotspot (Carter et al. 2015). Our research questions are (1) what is the density and population size of tigers and leopards, (2) what factors influence the spatial distribution of tigers and leopards (3) do their diurnal activity patterns differs, and (4) what is their dietary composition and overlap. We tested the broad hypothesis that co-occurrence of tigers and leopards in Chitwan is facilitated by the temporal and spatial segregation of habitats with varying degree of prey and human disturbances. Our results will have implications on conservation of these large carnivores in human-dominated landscapes.

\section{Materials and methods}

\section{Study area}

Our study was conducted in Chitwan NP $\left(27^{\circ} 16.56^{\prime}-27^{\circ} 42.14^{\prime} \mathrm{N}\right.$ and $83^{\circ} 50.23^{\prime}-84^{\circ} 46.25^{\prime} \mathrm{E}$; area $953 \mathrm{~km}^{2}$ ), and adjoining forests $\left(495 \mathrm{~km}^{2}\right)$. CNP, a World Heritage Site, is the flagship park in Nepal, well known for its biodiversity with species diversity of $\sim 70$ mammals, $>600$ birds, 49 reptiles and amphibians, 156 butterflies, and 120 fish species (CNP 2013). The Park is contiguous to Parsa National Park on the east and Valmiki Tiger Reserve (India) on the south (UNESCO 2003). These three adjacent forests combined make it one of the largest intact forest patches $\left(\sim 3500 \mathrm{~km}^{2}\right)$ in the TAL (Lamichhane et al. 2018b). CNP is connected to the Hill forests of Mahabharat (outer Himalayas) on the north through a forest corridor called Barandabhar (Fig. 1). The Park is characterized by a monsoon-dominated sub-tropical climate with an average monthly maximum temperature of $24{ }^{\circ} \mathrm{C}-38{ }^{\circ} \mathrm{C}$, monthly minimum temperature $11-26^{\circ} \mathrm{C}$, annual rainfall $\sim 2250 \mathrm{~mm}$ and relative humidity 89-98\% during 2000-2010 (Subedi et al. 2017). Sal (Shorea robusta) dominated forest is the climax vegetation covering nearly $70 \%$ of the Park where wildlife density is relatively low. Floodplain grasslands (9.6\%) and riverine forests in different stages of succession (10\%) support a high density of wildlife. Different waterbodies (rivers, streams, oxbow lakes) cover 3\% of the Park (Thapa 2011).

CNP is recognized as one of the core breeding sites of the tigers globally (Walston et al. 2010) and contains a major population of leopards (Thapa 2011). Other carnivores such as Asiatic wild dog (Cuon alpinus), striped hyena (Hyaena hyaena), clouded leopard (Neofelis nebulosa) and three smaller cats (fishing cat Prionailurus viverrinus, Jungle cat Felis chaus and leopard cat Prionailurus bengalensis) (Lamichhane et al. 2014) also occur in the Park. A wide range of ungulates including chital (Axis axis), sambar (Rusa unicolor), hog deer (Axis porcinus), barking deer (Muntiacus vaginalis), wild boar (Sus scrofa), gaur (Bos gaurus), Nilgai (Boselaphus tragocamelus) and two primates (rhesus macaque Macaca mulatta and langur Semnopithecus hector) serve as prey species for the carnivores.

The Park is surrounded by a buffer zone $\left(729 \mathrm{~km}^{2}\right) \sim 5 \mathrm{~km}$ from the boundary. About half of the buffer zone is covered by forests/grasslands, the remaining half includes human settlements and agricultural areas (Karki et al. 2015). These buffer zone forests have significantly higher human pressure but increasingly are managed for national and foreign ecotourism safaris (Carter et al. 2015; Wegge et al. 2018). In addition, the communities 


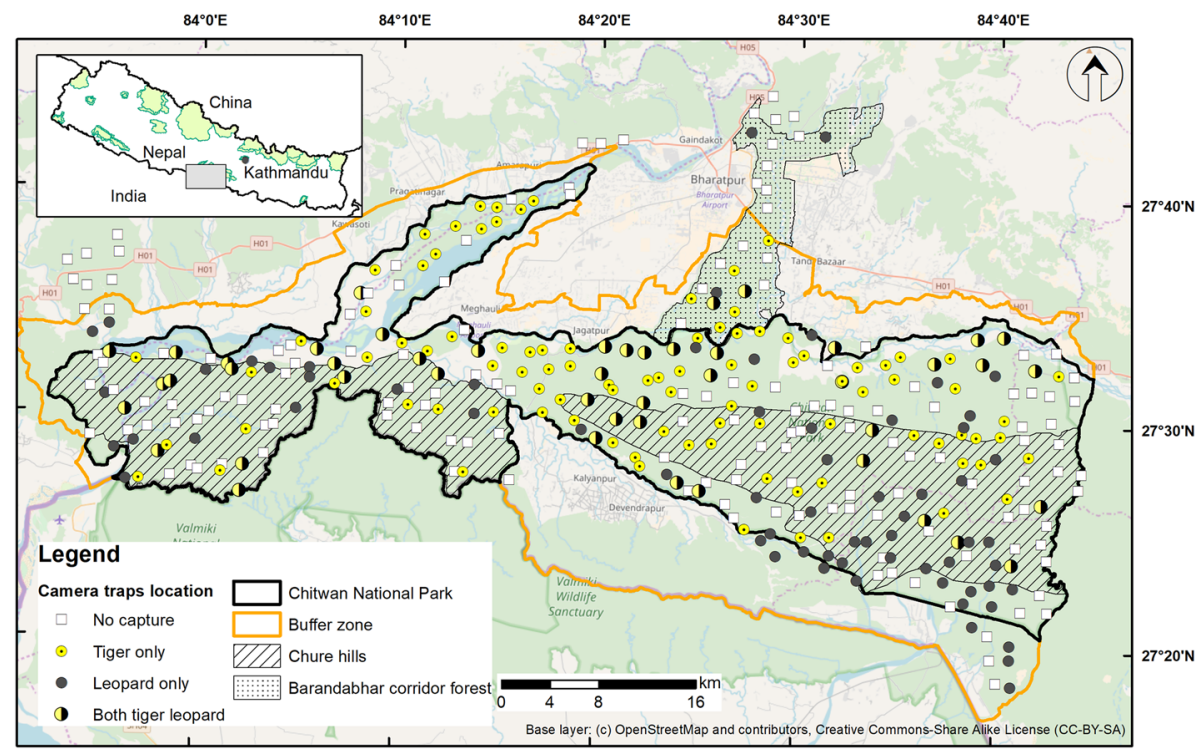

Fig. 1 Study area (Chitwan National Park and surrounding forests) showing locations of camera-traps and captures of tiger and leopard in 2013

exploit these forests for fodder, fuelwood, grazing and non-timber forest products following a regulated system of forest use. There are $>45,000$ households living in the buffer zone spread over 12 municipalities belonging to four states (2, 3, Gandaki, 5) and five districts (Chitwan, Makawanpur, Nawalpurasi East, Nawalpurasi West and Parsa) (Lamichhane et al. 2019). The majority of people rely on subsistence agriculture but dependence on agriculture is decreasing as the younger generation prefers off-farm activities such as tourism (e.g. nature-guides, jobs in hotels), national and foreign employment. Livestock has been an integral part of subsistence agriculture and until the last decade, open grazing was common in the buffer zone. With the establishment of community managed forests and grazing restrictions in these forests, a gradual shift has occurred towards stall feeding (Gurung et al. 2009). These changes are driven in part by adoption of improved livestock, commercialization of the farms and shortage of labor (Lamichhane et al. 2018a). Adjoining forests outside of the buffer zone (including state managed forests and community forests) administered by the Department of Forests experience more human pressure from subsistence communities as timber exploitation is the focus of the management instead of wildlife conservation or tourism.

\section{Camera-trap survey}

We set 362 camera-trap grid cells with a spacing of $2 \mathrm{~km}$ in Chitwan National Park and adjoining forests $\left(\sim 1450 \mathrm{~km}^{2}\right)$ (Karanth and Nicholas 1998). A pair of motion sensor digital camera-traps (Reconyx $500 \& 550$, Bushnell Trophy Cam HD) were deployed in each cell during the dry season in 2013 (18 Feb-04 May). Cameras were set to take three pictures per trigger with no delay to ensure complete capture of animals within $15 \mathrm{~m}$ distance of the camera trap. Camera-traps were active $24 \mathrm{~h}$ in in each site for a 
minimum of 15 days and checked twice a week. Due to limited availability of cameratraps and logistical challenges, the survey area was divided into four blocks that ranged from 272 to $423 \mathrm{~km}^{2}$; these were surveyed successively. Prior to camera deployment, intensive sign surveys helped us identify potential survey sites to increase the probability of photographing tigers/leopards and maximize camera safety. Camera-traps were mounted on trees or on wooden poles $45 \mathrm{~cm}$ above the ground, perpendicular to, and 5-7 $\mathrm{m}$ apart on either side of game trails, forest roads, and riverbeds without using lure. Tiger and leopard photographs obtained in camera-traps were systematically sorted in separate folders. Paired camera-traps at each sampling point obtained photos of both flanks of tigers and leopards in most of the events $(\sim 80 \%)$ which enabled us to identify individuals accurately based on their coat marking patterns (Karanth and Nicholas 1998; Thapa et al. 2014). Because paired cameras operated independently, $\sim 20 \%$ of capture events were composed of photos of a single flank.

Individual identification was conducted by three independent observers and crossverified collectively where 4-7 observers participated. We also used Extract-Compare Software to verify manually identified tiger and leopard individuals (Hiby et al. 2009).

\section{Estimating population and density}

We estimated density and population size of tigers and leopards through Baysean Spatially-Explicit Capture-Recapture Bayesian (B-SECR) models implemented in the package 'SPACECAP' (Gopalaswamy et al. 2012) in R 3.4.0 (R Core Team 2017). SPACECAP requires three input files i.e. (1) tiger capture history with location, animal ID and sampling occasion; (2) camera activity records (1-active and 0 -not-active) for each camera-trap location and sampling occasion; and (3) home range centres. Around a $15 \mathrm{~km}$ buffer of the camera locations, equally spaced points (580 m apart, a grid size of $0.336 \mathrm{~km}^{2}$ ) were generated to represent hypothetical home range centers $(n=13,288)$. This resulted in an area of $3854 \mathrm{~km}^{2}$ of tiger and leopard habitat after removing the $2739 \mathrm{~km}^{2}$ area of settlements. We ran the analysis with four different combinations (1) trap response present, (2) trap response absent, (3) half-normal and (4) negative-exponential detection functions and reported the density and population size obtained from the best-performing model (Gopalaswamy et al. 2012). We ran a Markov Chain Monte Carlo (MCMC) over 100,000 iterations with a burn-in of 10,000 and a thinning rate of 5. An augmentation value of 400 and 350 (more than five times the number of animals captured or $\mathrm{Mt}+1$ ) was set for tigers and leopards respectively. We produced a pixelated map of tiger and leopard density at the size of home range center $\left(0.336 \mathrm{~km}^{2}\right)$ and calculated average density within each survey grid $\left(2 \times 2 \mathrm{~km}^{2}\right)$ using QGIS (QGIS Development Team 2016).

We estimated the tiger and leopard abundance by multiplying the estimated density from B-SECR models with the respective effective sampled areas (Srivathsa et al. 2015). Effective sampling area was calculated following Srivathsa et al. (2015). Estimated sigma $(\sigma)$ value was derived from converged B-SCR models for tigers and leopards and a buffer of sigma $(\sigma) \times$ sqrt $(5.99)$ was added to the camera trap array (Thapa and Kelly 2017). Effective sampling area was obtained by removing the non-habitat (settlement and agriculture) from the buffer area. For abundance and density estimates, we reported the $95 \%$ credible intervals around the point estimate. 


\section{Factors associated with tiger and leopard distribution}

We used a binomial logistic regression by constructing a Generalized Liner Model (GLM) to analyze the variables associated with tiger and leopard occurrence in a location measured as detection in camera-traps (Zuur et al. 2009). In the GLM, occurrence of tigers or leopards within each camera trapping grid was used as response variable. Fourteen explanatory variables representing environmental parameters, prey distribution and anthropogenic pressure were defined. The environmental variables included coverage area of four habitat types (grassland, Sal forest, riverine forests and waterbodies) within grid, physiography (flat or churia hills) and average ruggedness of the terrain. The ruggedness index was calculated in QGIS from the $30 \mathrm{~m}$ resolution digital elevation model of ASTER satellite images (QGIS Development Team 2016). Land cover data obtained from classification of $30 \mathrm{~m}$ resolution landsite satellite images was grouped into four habitat types and area of the habitat in each cell was calculated in QGIS (Thapa 2011).

Similarly we used the independent detection frequency of three major prey species (chital, sambar and muntjac) (Karanth and Sunquist 1995) in camera trap photos as explanatory variables. Photographs of a prey species or people captured within an hour was recorded as one independent detection. Anthropogenic pressure was represented by the number of independent detections of local people and livestock in the camera trap photos. Distance to forest edge (assuming closer the edges, higher the anthropogenic activities) and management type (assuming low human pressure in Park core areas and high pressure in forests outside) were also used as a measure for anthropogenic pressure. In addition, average density of other large cat within grid cell obtained from the pixelated density output of SPACECAP was also used as an explanatory variables. Using multi-model inference in 'MuMIn' package in R (Grueber et al. 2011), we ranked the best models based on AIC value (lower AIC value indicates higher model ranking). Final models for the tiger and leopard were obtained by averaging the top candidate models supporting the data equally well (AICc $\leq 2$, Burnham and Anderson 2003). Analysis was done in R (R Core Team 2017). All the analyses can be reproduced using the R-script and the associated data provided in the Supplementary Files (S1-S8).

\section{Temporal activity patterns}

Temporal activity pattern and extent of overlap between tiger and leopard were calculated using (1) a non-parametric kernel density function of activity detected by camera-traps (Ridout and Linkie 2009), (2) coefficient of overlaps, $\hat{\Delta}$, ranging from 0 (no overlap) to 1 (complete overlap) and (3) a non-parametric Kolmogorov-Smirnov test to compare activity distributions. The time stamp of each independent detection (photograph taken at least $30 \mathrm{~min}$ apart at the same camera-trap station) was used to fit the density function of the activity pattern. We used 10,000 bootstrap samples to measure $\hat{\Delta}$ 95\% confidence intervals (CI) (Ridout and Linkie 2009). We compared the activity pattern and calculated the overlap coefficient between tigers and leopards for locations (a) where both tigers and leopards occurred and (b) where either tiger or leopards occurred. The analysis was conducted using the 'overlap' package in R (R Core Team 2017). 


\section{Diet of tigers and leopards}

Scat samples of tigers and leopards (all that were found intact and carnivore species could be verified) were collected along the roads, trails and streambeds in Chitwan National Park and Barandabhar corridor forest between January and March 2017. Although there was 4 years gap between the camera-trap survey and the diet study, we assume no substantial change in prey availability. Experienced observers can make the distinction between tiger and leopard scats fairly accurately based on size and morphology as well as the presence of secondary signs such as scrape marks and pugmarks (Simcharoen et al. 2018; Bhattarai and Kindlmann 2012b). Tiger tracks ( $>8 \mathrm{~cm}$ pad width) and scrapes $(>35 \mathrm{~cm}$ long and $>19 \mathrm{~cm}$ wide $)$ are larger than leopard tracks $(<6.5 \mathrm{~cm}$ pad width) and scrape $(<25 \mathrm{~cm}$ long and $<15 \mathrm{~cm}$ wide). In a similar study in Bardia NP, using molecular identification of the carnivore, Upadhyaya et al. (2018) reported high accuracy of field identification of scats $(n=101)$. Prey remains in the scat such as hairs, feathers, bones, hooves and teeth were separated. Prey species in the scat were primarily identified through microscopic analysis of medullary and cuticular hair structures as described by Mukherjee et al. (1994). Microscopic analysis of hair was carried out at the laboratory of NTNC's Biodiversity Conservation Center, Chitwan. Prey species present in the scat were identified by comparisons of hair structure with reference samples maintained at NTNC and the Wildlife Institute of India (Bahuguna 2010). We used the non-linear (asymptotic) model developed by Chakrabarti et al. (2016) for calculation of the biomass consumed by tigers and leopards following Simcharoen et al. (2018). We also evaluated tiger-leopard diet overlap by using Pianka's index $(\mathrm{O})$ which ranges between 0 (total separation) and 1 (total overlap) (Gotelli 2001).

\section{Results}

\section{Density and abundance of tigers and leopards}

A total sampling effort of 6085 trap-nights yielded 2950 tiger and 1453 leopard photographs in 329 and 209 independent detections respectively. Of the 362 sampling locations, tigers were detected from 143 locations; leopards from 110, including 47 locations where both species were photographed. Out of 78 tiger and 71 leopard individuals identified, we included in our analysis 71 tigers and 65 leopards identified from photos showing either both flanks or right flank for capture-recapture analysis and excluded 7 tigers and 6 leopards showing only the left flank in photos to avoid possible duplication (Table 1).

All model parameters in Bayesian spatial capture-recapture (in program SPACECAP) for both tigers and leopards converged based on Geweke diagnostic statistics (z scores less than 1.6) on the best performing models (trap-response present with negative exponential detection function for tiger and trap response present with half normal detection function for leopard $)$. The tiger density was estimated $3.2-4.6($ mean $=3.94, \mathrm{SE}=0.37)$ individuals per $100 \mathrm{~km}^{2}$. Tiger density was highly concentrated in the floodplain areas close to the rivers in the northern part of the Park (Fig. 2a, c). Similarly, leopard density was estimated 2.6-4.1 (mean =3.31, $\mathrm{SE}=0.39$ ) animals per $100 \mathrm{~km}^{2}$ in $\mathrm{CNP}$ and adjoining forests. We estimated population size of tiger between 70 and $102(86 \pm 8)$ and leopard between 66 and $105(85 \pm 10)$ based on density and effective sampled area $\left(2142.2 \mathrm{~km}^{2}\right.$ for tiger and 
Table 1 Details of tiger and leopard capture in camera-traps in Chitwan National Park, Nepal during survey between February and May 2013 ( $M$ males, $F$ females, $U$ sex undetermined)

\begin{tabular}{lll}
\hline Parameters & Tiger & Leopard \\
\hline Number of camera stations with capture & 143 & 110 \\
Number of independent detections & 329 & 207 \\
Capture rate (number of detections per & 5.4 & 3.4 \\
$\quad$ & & \\
Number trap days) & $78(50 \mathrm{~F}$, & $71(32 \mathrm{~F}$, \\
& $18 \mathrm{M}$, & $27 \mathrm{M}, 11$ \\
& $10 \mathrm{U})$ & $\mathrm{U})$ \\
Both flanks & 61 & 58 \\
Right flank only & 10 & 7 \\
Left flank only & $7^{\mathrm{a}}$ & $6^{\mathrm{a}}$ \\
\hline
\end{tabular}

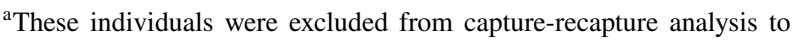
avoid any duplication

$2571.1 \mathrm{~km}^{2}$ for leopard) (Table 2). We also generated surface density maps (Gopalaswamy et al. 2012) to visually depict posterior estimates of pixel-level densities of tigers and leopards in the landscape at the scale of $0.3364 \mathrm{~km}^{2}$ (Fig. 2a, b). Density of leopards was higher close to the forest edges and decreased with increasing distance (Fig. 2b, c).

\section{Factors related to tiger and leopard occurrence}

Based on the averaged value of the top candidate models, tiger detection in the camera trap survey grid cell was positively related to the area of grassland and riverine forest, detection of chital and core areas of the Park but negatively related to livestock presence (Table 3). In contrast to tigers, the leopards were more likely to be detected in the grids containing larger areas of sal forest as well as presence of chital and livestock (Table 3).

\section{Activity pattern}

Both tigers and leopards showed a crepuscular activity pattern, although this was more pronounced in tigers (Fig. 3). There was a high overlap $\hat{\Delta}=0.83(0.78-0.91)$ ) in temporal activity of both species across all habitats. Activity overlap was $\hat{\Delta}=0.72(0.61-0.82)$ in the locations where tiger and leopard co-occurred and it was $\hat{\Delta}=0.87(0.84-0.95)$ where tigers and leopards were captured separately (Fig. 3a, b). Activity density of tigers peaked just before sunrise and after sunset whereas, leopard activity peaked exactly at the sunrise and sunset. Comparatively leopards were more active during the day in the areas where they co-occurred with tigers. A Kolmogorov-Smirnov test showed the activity distribution of tigers and leopards differ significantly $(p=0.011)$ at locations where both species were photographed. However, their activity distribution did not differ $(p=0.478)$ at locations where just one species was detected in a camera trap.

\section{Diet of tiger and leopard}

Among the prey species, chital contributed the highest biomass in the diet of tigers (38\%) and leopards (48\%). Tigers, however, consumed a greater biomass of the large prey such as 
sambar (22\%) and gaur (2.3\%) compared with leopards (12\% and 0\% respectively). Estimated consumed biomass of livestock was higher in leopard diet (15\%) compared with tiger (3\%) (Fig. 4a). Analysis using Pianka's prey overlap index demonstrated a 90.0\% overlap in tiger and leopard diet.

\section{Discussion}

We documented a relatively high density of two sympatric carnivores in a national park and adjoining forests interspersed in a human-dominated landscape. We also observed spatial and temporal segregation between tigers and leopards, thus supporting our hypothesis. Tiger distribution was positively related to the habitats in the river floodplain (alluvial grasslands and riverine forests) and prey, but were negatively related to the disturbance (livestock presence and forests outside of CNP). In contrast, leopard distribution was positively related to less productive habitat i.e. sal forests, locations with livestock presence (disturbance) and prey species (chital). Leopards also adjusted their activity (increased in the daytime when tigers are less active) in locations where they co-occur with tigers. Both tiger and leopard occurrence showed a significant positive relationship with detection of chital in camera traps which was expected as chital constitutes a major portion of tiger and leopard diet. However, habitat type was different for tigers and leopards. The mosaic of habitats and different levels of anthropogenic pressures in these habitats have facilitated co-occurrence of tigers and leopards as they are able to occupy different niches in time and space (Karanth et al. 2017).

\section{Tiger-leopard density}

Our density estimates of tigers and leopards are comparable with those reported in previous studies (Thapa 2011; Karki et al. 2015). Karki et al. (2015) estimated 4.5 tigers per $100 \mathrm{~km}^{2}$ in CNP. In India, tiger densities (SECR based) range between 1.15 and 8.9 animals per $100 \mathrm{~km}^{2}$ (Kalle et al. 2011). Much lower tiger densities (individuals $100 \mathrm{~km}^{2}$ ) are reported from other tiger range countries like Lao PDR (0.2-0.7; Johnson et al. 2006), Bhutan (0.52; Wang and Macdonald 2009), Malaysia (1.1-1.8; Kawanishi and Sunquist 2004) and Thailand (2.0; Duangchantrasiri et al. 2016). Tiger density in Chitwan NP is also high when compared to that recorded in other parks in Nepal (Bardia NP-3.3, Shuklaphanta NP-3.4, Parsa NP- 1.4, Banke NP-0.16; Dhakal et al. 2014; Lamichhane et al. 2018a).

Leopard density in our study is also close to the estimates reported by Thapa (2011) for CNP (3.4 leopards per $100 \mathrm{~km}^{2}$ ) and Thapa et al. (2014) for Parsa NP (3.5 per $100 \mathrm{~km}^{2}$ ). The density estimate of 3.9 individuals per $100 \mathrm{~km}^{2}$ in a protected forest in Cambodia (Gray and Prum 2012) is comparable to our estimates. But the mountainous terrain in Bhutan has a much lower leopard density (1.04 individuals per $100 \mathrm{~km}^{2}$ ). In India, the leopard density varied in parks between 2.07 and 13.1 individuals per $100 \mathrm{~km}^{2}$ (Harihar et al. 2011; Kalle et al. 2011; Thapa et al. 2014).

A decrease in leopard density (9.76 to 2.07 individuals per $100 \mathrm{~km}^{2}$ ) with an increase of tiger density ( 2.67 to 5.8 individuals per $100 \mathrm{~km}^{2}$ ) has been reported from India (Harihar et al. 2011). In contrast we found both tiger and leopard densities increased over the last decade in CNP and remained relatively stable in few years before the survey (2010-2013) (Thapa 2011; Karki et al. 2015). Similar observations of leopards (in high density) that 
Fig. 2 Density heat map obtained from SECR-B implemented in SPACECAP for a tiger; b leopard in Chitwan NP and surrounding forests; and c Average tiger/leopard density in each survey grid (calculated from modeled density surface created using pixel density obtained from SPACECAP) in relation to the distance to forest edge

were unaffected by interference from lions, another apex predator, was reported from Sabi Sand Game Reserve in South Africa (Balme et al. 2017). For a multiple decades, tigers and leopards have co-occurred with a large overlap of home range and diet (Seidensticker 1976). Factors facilitating the high density of these two large cats in Chitwan may be a combination of high density of ungulates (73 prey per $\mathrm{km}^{2}$, Dhakal et al. 2014), mosaics of the habitats (Bhattarai and Kindlmann 2012a), control of hunting with enhanced protection, habitat restoration in the buffer zone (Gurung et al. 2008) and support from local communities (Nepal and Spiteri 2011; Lamichhane et al. 2019).

\section{Spatial distribution of tiger and leopard densities}

Carnivore density is not evenly distributed in CNP but concentrated in certain patches. Contrary to the general expectation, both tiger and leopard densities were estimated to be relatively higher near the Park boundary. The Park is bordered by three major rivers which creates highly productive floodplains with alluvial grasslands and riverine forests that harbor a high density of ungulates and lie in proximity to these rivers (Lehmkuhl 1994; Shrestha 2004). Thus, a high tiger density close to the Park edges is a function of ecological factors (highly productive alluvial grasslands and riverine forests) (Sunquist 1981; Smith 1993). Similarly, leopard density was also higher close to the Park boundary or forest edge and decreased with increasing distance. Such a pattern of leopards using fringe areas has also been documented in Bardia and Shuklaphanta National Parks of TAL Nepal (Odden et al. 2010; Pokheral and Wegge 2018) and Rajaji of TAL India (Harihar et al. 2011). High densities of large carnivores (both tigers and leopards) and their prey in close proximity to the Park boundaries may help to explain the high incidence of human-wildlife conflict in CNP (Average annual 9.3 \pm SD 5.7 human death, 31.3 \pm SD 11.8 human injury and $122.94 \pm$ SD 80.97 livestock depredation) compared with other parks in Nepal (Bhattarai and Fischer 2014; Lamichhane et al. 2018a).

The physiography of the Park may also have facilitated the uneven density distribution of tigers and leopards. The Churia Hills, covering $>60 \%$ of the Park (Thapa and Kelly 2017), stretch east to west in the middle of the Park. Lower prey density in these Hills resulted in lower use of higher elevations by tigers (Smith et al. 1989). Recent studies have documented both tigers and leopards occupying this habitat (Karki et al. 2015) but in lower densities i.e. 1.5 tigers and 2.1 leopards per $100 \mathrm{~km}^{2}$ (Thapa and Kelly 2017).

Tigers were concentrated in the prime habitats having a high density of prey species and leopards in comparatively marginal habitats. A higher proportion of livestock in the diet of leopards compared to that in tiger diet also supports the leopard use of the boundary of CNP and buffer zone area where local communities graze their cattle occasionally. We assume that interference competition by tigers led to habitat segregation by these two species (Seidensticker 1976; Carter et al. 2015). The density heatmap shows that high density areas of tigers and leopards are mostly separated from each other except for a small overlapping areas in the northern portion of the study area (Barandabhar Corridor Forest). A high number of livestock attacked by leopards has been reported by communities in recent years near the corridor forest where such a concentration of carnivores was observed 

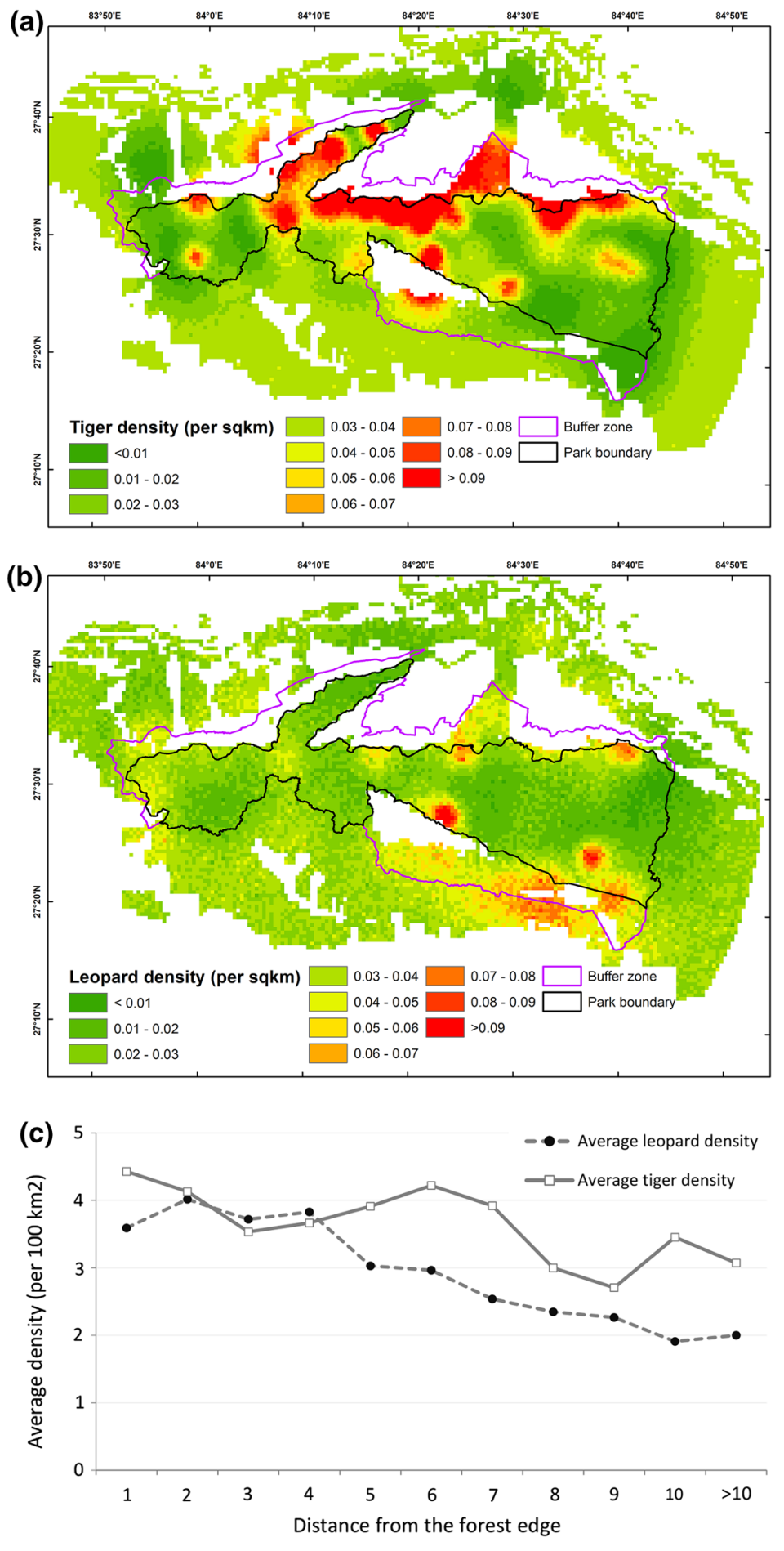
Table 2 Estimates of tiger and leopards density (animals $100 \mathrm{~km}^{-2}$ ) and abundance (N) for Chitwan National Park, Nepal obtained from Bayesian spatially explicit capture-recapture (B-SCR) implemented in SPACECAP (Gopalaswamy et al. 2012) along with the posterior summaries of model parameters (sigma, lamda, beta, psi, p1 and p2)

\begin{tabular}{|c|c|c|c|c|c|c|}
\hline \multirow[t]{2}{*}{ Parameters } & \multicolumn{3}{|l|}{ Tiger } & \multicolumn{3}{|l|}{ Leopard } \\
\hline & Estimate \pm SD & $95 \% \mathrm{CI}$ & $\begin{array}{l}\text { Gweke } \\
\text { diagnosticslz } \\
\text { scorel }\end{array}$ & Estimate $\pm \mathrm{SD}$ & $95 \% \mathrm{CI}$ & $\begin{array}{l}\text { Gweke } \\
\text { diagnosticslz } \\
\text { scorel }\end{array}$ \\
\hline $\operatorname{Sigma}(\sigma)$ & $5089.2 \pm 191.0$ & $4746-5475$ & 1.2956 & $7002.52 \pm 604.67$ & $5841-8176$ & -0.0716 \\
\hline Lamda $(\lambda 0)$ & $0.029 \pm 0.004$ & $0.021-0.038$ & -1.2801 & $0.003 \pm 0.001$ & $0.003-0.004$ & -0.1049 \\
\hline $\operatorname{Beta}(\beta)$ & $1.33 \pm 0.19$ & $0.97-1.71$ & 0.5596 & $3.28 \pm 0.23$ & $2.84-3.74$ & -0.1471 \\
\hline Psi $(\psi)$ & $0.32 \pm 0.04$ & $0.25-0.39$ & -0.4057 & $0.31 \pm 0.04$ & $0.23-0.39$ & 0.989 \\
\hline $\mathrm{N}$-super & $152 \pm 14$ & $123-179$ & -0.2921 & $128 \pm 15$ & $99-157$ & 0.807 \\
\hline Density (D) & $3.94 \pm 0.37$ & $3.19-4.64$ & & $3.31 \pm 0.39$ & $2.57-4.07$ & \\
\hline $\mathrm{p} 1$ & $0.028 \pm 0.004$ & $0.02-0.037$ & & $0.003 \pm 0.001$ & $0.003-0.004$ & \\
\hline $\mathrm{p} 2$ & $0.103 \pm 0.014$ & $0.076-0.131$ & & $0.072 \pm 0.011$ & $0.051-0.095$ & \\
\hline $\begin{array}{l}\text { Effective } \\
\text { sampling area } \\
\left(\mathrm{km}^{2}\right)\end{array}$ & 2142.2 & & & 2571.1 & & \\
\hline$\tilde{\mathrm{N}}$ & $86 \pm 8$ & $70-102$ & & $85 \pm 10$ & $66-105$ & \\
\hline
\end{tabular}

(Lamichhane et al. 2018a). With the increasing number of tigers dispersing from parks to the corridor forests, leopards may have been pushed into the edges where they kill the livestock (Odden et al. 2010; Lamichhane et al. 2018a).

\section{Daily activity pattern and diet}

Both tiger and leopard showed nocturnal behavior with pronounced activities during dawn and dusk. Tiger activity intensity was less during daytime (6:00-18:30) $(<30 \%$ of total activity) compared to that of leopards ( $\sim 40 \%$ of the activities during day). Both tiger and leopard activity coincides closely with higher overlap (0.87) in locations where only a single species was photographed. The activity overlap decreased (0.72) and activity distribution of the two species differed significantly in areas where both species occurred. Decrease in overlap is primarily due to leopards being more diurnal in the presence of tigers. More than $50 \%$ of the leopard activities were diurnal in locations overlapped with tigers and it declined to $<40 \%$ diurnal in areas where tigers were absent. Thus, leopards exhibited temporal avoidance of tigers. Kawanishi and Sunquist (2004) also observed a shift in leopard behavior to more nocturnal activity in the absence of tigers but Rayan and Linkie (2016) reported no temporal avoidance of leopard.

Scat analysis demonstrated that chital was the most important (estimate as biomass) species in the diet for both tigers and leopards as observed in other studies (Lovari et al. 2015; Wegge et al. 2018). Although there was a large overlap in prey of tigers and leopards, niche separation in the diet was observed with tigers preferring larger-sized prey (Bhattarai and Kindlmann 2012b). Rosenzweig (1966) showed coexistence between predator species is the result of size difference leading one species to hunt a different set of prey species. Wild prey contributed to most of the diets of tigers and leopards indicating that prey is not a limiting factor in the Park and buffer zone. Prey occurs in relatively high densities in CNP and 
Table 3 Model averaged parameter values of individual variables (Supplementary Information S2 and S8) obtained from the GLM fitted to Tiger (A) and Leopard (B) occurrence in each camera trapping survey grids during a camera-trap survey in Chitwan National Park, 2013

\begin{tabular}{lllll}
\hline Parameters & Estimate & Unconditional SE & Z value & $\begin{array}{l}\text { Relative } \\
\text { importance }\end{array}$ \\
\hline
\end{tabular}

\begin{tabular}{|c|c|c|c|c|c|}
\hline \multicolumn{6}{|l|}{ (A) Tiger } \\
\hline (Intercept) & -2.087 & 0.592 & 3.516 & - & $<0.001 * * *$ \\
\hline Chital & 0.064 & 0.027 & 2.326 & 1.00 & $0.020^{*}$ \\
\hline Grassland & 0.006 & 0.003 & 1.992 & 1.00 & $0.046^{*}$ \\
\hline Livestock & -0.130 & 0.066 & 1.981 & 0.97 & $0.048 *$ \\
\hline Management_CNP & 0.843 & 0.405 & 2.074 & 0.93 & $0.038 *$ \\
\hline Muntjac & 0.082 & 0.047 & 1.732 & 0.92 & 0.083 \\
\hline Riverine_forest & 0.942 & 0.353 & 2.658 & 0.75 & $0.008 * *$ \\
\hline Sal_forest & 0.180 & 0.111 & 1.611 & 0.70 & 0.107 \\
\hline Sambar & 0.057 & 0.032 & 1.769 & 0.64 & 0.077 \\
\hline Physio_Lowland & 0.452 & 0.299 & 1.508 & 0.44 & 0.132 \\
\hline Ruggedness & -0.003 & 0.003 & 1.010 & 0.24 & 0.313 \\
\hline Waterbodies & 0.609 & 0.664 & 0.914 & 0.19 & 0.361 \\
\hline Local_people & -0.043 & 0.037 & 1.150 & 0.16 & 0.250 \\
\hline Leopard_density & -0.167 & 0.154 & 1.080 & 0.10 & 0.280 \\
\hline \multicolumn{6}{|l|}{ (B) Leopard } \\
\hline (Intercept) & -1.613 & 0.378 & 4.258 & - & $<0.001 * * *$ \\
\hline Chital & 0.051 & 0.025 & 2.031 & 1.00 & $0.042 *$ \\
\hline Livestock & 0.118 & 0.044 & 2.701 & 1.00 & $0.007 * *$ \\
\hline Sal_forest & 0.203 & 0.104 & 1.938 & 1.00 & $0.053 *$ \\
\hline Sambar & 0.035 & 0.027 & 1.294 & 0.31 & 0.196 \\
\hline Waterbodies & 0.773 & 0.639 & 1.206 & 0.29 & 0.228 \\
\hline Ruggedness & 0.003 & 0.002 & 1.062 & 0.23 & 0.288 \\
\hline Tiger_density & -0.052 & 0.049 & 1.062 & 0.21 & 0.288 \\
\hline Grassland & 0.002 & 0.002 & 0.934 & 0.10 & 0.350 \\
\hline Distance_forest_edge & -0.027 & 0.046 & 0.59 & 0.05 & 0.555 \\
\hline Management_CNP & 0.179 & 0.310 & 0.574 & 0.05 & 0.566 \\
\hline Physio_Lowland & -0.136 & 0.254 & 0.535 & 0.05 & 0.593 \\
\hline
\end{tabular}

$* \mathrm{p}$ between 0.05 and 0.01 , **p between 0.01 and $0.001, * * * \mathrm{p}<0.001$

the buffer zone (73 prey animals $/ \mathrm{km}^{2}$; Dhakal et al. 2014) but density is very low in the forests outside these areas due to high anthropogenic pressure and possibly hunting (Shrestha 2004; NTNC unpublished data). Increasing wild prey density in these forests is important to sustain the high density of tigers/leopards and reduce livestock depredation especially from dispersing (or pushed out) large cats (Lamichhane et al. 2017; Kolipaka 2018).

Livestock contributed to only a small portion of the big cats' diets in Chitwna NP; lower than the previously reported by Bhattarai and Kindlmann (2012b). Kapfer et al. (2011) also reported small contribution $(<1 \%)$ of livestock in big cat diet. Reduced availability of livestock in forests due to grazing restrictions in the Park and community managed buffer zone forests may have led to lower encounter of livestock by tigers and leopards (Gurung et al. 2009) which is also reflected in their diets. Annual average of 50.6 incidents of livestock depredation in the buffer zone of CNP during 2011-2016 (Lamichhane et al. 2018a) is 

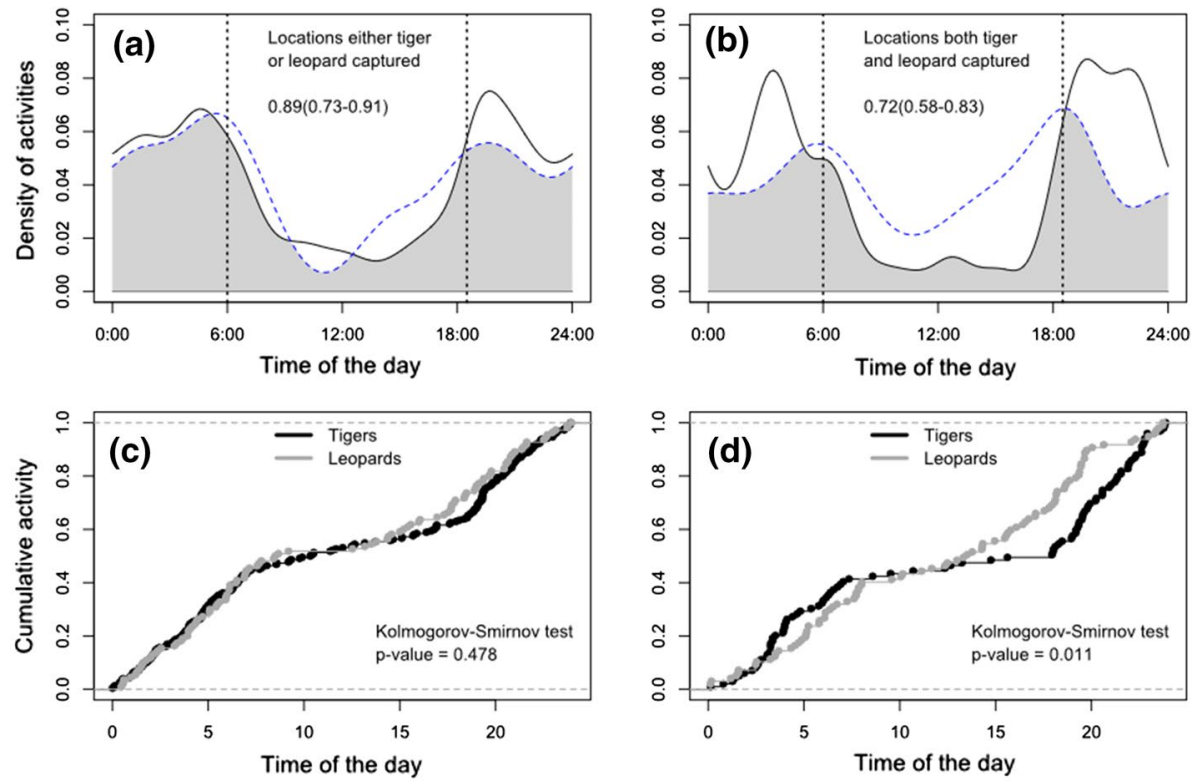

Fig. 3 Temporal activity pattern of Tigers and Leopards in locations where only tiger or leopard occurred $(\mathbf{a}, \mathbf{c})$ and locations where both tiger and leopard occurred $(\mathbf{b}, \mathbf{d})$. On the figures of first row (a, b), the shaded area represents the overlap, the continuous and dashed lines represent the activity of tigers and leopards respectively as detected in camera-traps. The vertical dotted line represents sunrise (6:00) and sunset (18:30) during the survey period. The figures on lower row (c, d) shows the cumulative activity over the hour of the day

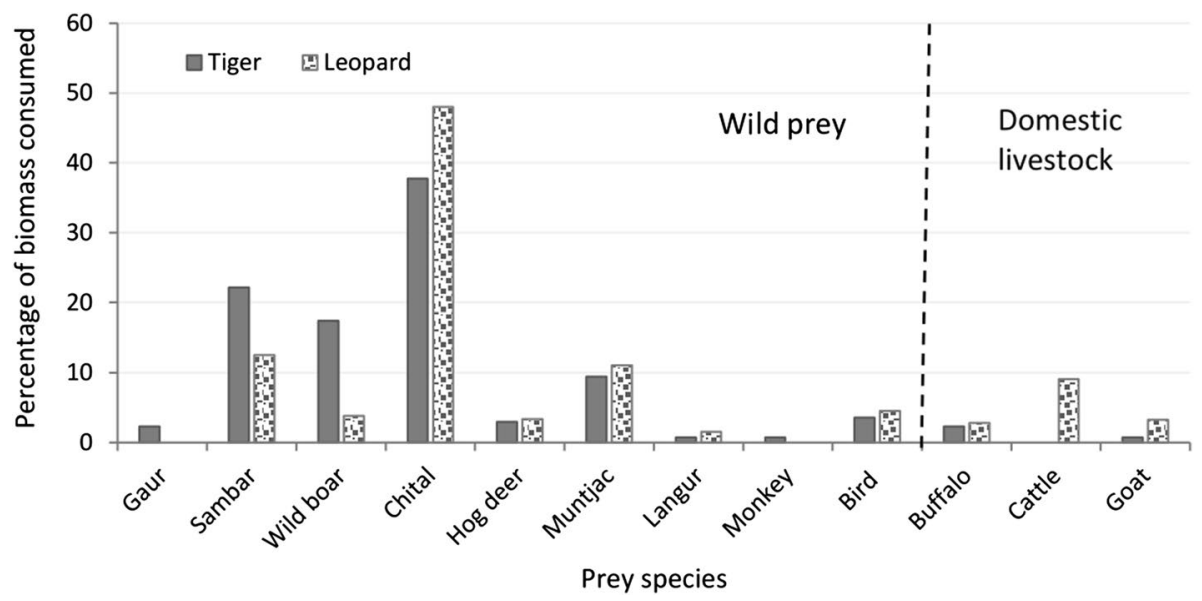

Fig. 4 Proportion of prey biomass consumed by tigers and leopards in Chitwan National Park and surrounding forests

low when compared to data from parks in India (462/year, Kanha NP; Miller et al. 2016) where free grazing is common. Lamichhane et al. (2018a) reported a higher frequency of livestock depredations caused by leopards versus tigers during 2014-2016. Comparatively 
more leopard scats were detected in the buffer zone or corridor forest $(82 \%, \mathrm{n}=57)$ while more tiger scats were detected in the Park $(53 \%, \mathrm{n}=148)$ suggesting leopards are being pushed out of the CNP (Bhattarai and Kindlmann 2012b).

\section{Conservation implications}

Our study documents a unique scenario of large carnivores co-occurring in high density with spatial and temporal segregation within a human-dominated landscape. The high density of large cats in alluvial floodplains close to the Park boundaries should be considered while designing strategies to conserve these carnivores and minimize their impacts on humans. Additionally, managing the mosaic of habitats will help to maintain the diversity and density of prey to support tigers and leopards. High and stable densities of tigers in the core areas of CNP in recent years may have increased recruitment of tigers and resulted in higher rates of dispersal. A result may be that more tigers are attempting to occupy buffer zone forests, ultimately exerting pressure on leopards to move into marginal habitats. With improved management in buffer zone forests (e.g. restoration of degraded forests, grasslands and wetland management), managers should expect higher densities of both tigers and leopards in these forests. Strategies to increase prey density and reduce livestock depredation should be adopted in buffer zones or outside forests to reduce potential conflict with humans. Regular monitoring of wildlife, especially in the fringe areas, will help improve understanding of the interactions between carnivores and humans. Monitoring will also help to reduce conflict by establishing an early warning of the vulnerable communities when tigers and leopards are in close proximity.

Acknowledgements We thank Department of National Parks and Wildlife Conservation, Nepal for coordinating the survey. We also thank Chitwan National Park (CNP) for allowing us to conduct this research. We acknowledge the technical and financial support of National Trust for Nature Conservation (NTNC) and World Wildlife Fund - Nepal. Leiden University, Netherlands and the University of Antwerp, Belgium supported at different stages of manuscript preparation and publication. We are also grateful for assistance from field technicians from NTNC and CNP as well as from community members, student volunteers and the entire team involved in the survey. We acknowledge James L.D. Smith and Francesca Cuthbert who improved the manuscript by editing earlier versions. Babu Ram Lamichhane was supported by Louwis Fellowship Fund (Leiden University). Additional funds were awarded by the Rufford Small Grants Foundation for the diet analysis of tigers and leopards. Finally, we extend sincere appreciation to US Fish and Wildlife Service, different international chapters of World Wildlife Fund and the USAID Hariyo Ban Program for funding the camera trapping surveys.

\section{Compliance with ethical standards}

Conflict of interest The authors declare that they have no conflict of interest.

Open Access This article is distributed under the terms of the Creative Commons Attribution 4.0 International License (http://creativecommons.org/licenses/by/4.0/), which permits unrestricted use, distribution, and reproduction in any medium, provided you give appropriate credit to the original author(s) and the source, provide a link to the Creative Commons license, and indicate if changes were made. 


\section{References}

Bahuguna A (2010) Species identification from guard hair of selected Indian mammals: a reference guide. Wildlife Institute of India, Dehradun

Balme GA, Pitman RT, Robinson HS et al (2017) Leopard distribution and abundance is unaffected by interference competition with lions. Behav Ecol 28:1348-1358. https://doi.org/10.1093/beheco/arx098

Bhattarai BR, Fischer K (2014) Human-tiger Panthera tigris conflict and its perception in Bardia National Park, Nepal. Oryx 48:522-528. https://doi.org/10.1017/S0030605313000483

Bhattarai BP, Kindlmann P (2012a) Habitat heterogeneity as the key determinant of the abundance and habitat preference of prey species of tiger in the Chitwan National Park, Nepal. Acta Theriol (Warsz) 57:89-97. https://doi.org/10.1007/s13364-011-0047-8

Bhattarai BP, Kindlmann P (2012b) Interactions between Bengal tiger (Panthera tigris) and leopard (Panthera pardus): implications for their conservation. Biodivers Conserv 21:2075-2094. https:// doi.org/10.1007/s10531-012-0298-y

Burnham KP, Anderson DR (2003) Model selection and multimodel inference: a practical informationtheoretic approach. Springer, New York

Carter N, Jasny M, Gurung B, Liu J (2015) Impacts of people and tigers on leopard spatiotemporal activity patterns in a global biodiversity hotspot. Glob Ecol Conserv 3:149-162. https://doi. org/10.1016/j.gecco.2014.11.013

Chakrabarti S, Jhala YV, Dutta S et al (2016) Adding constraints to predation through allometric relation of scats to consumption. J Anim Ecol 85:660-670. https://doi.org/10.1111/1365-2656.12508

Chanchani P, Lamichhane BR, Malla S, et al (2014) Tigers of the transboundary Terai arc landscape: Status, distribution and movement in the Terai of India and Nepal. New Delhi

CNP (2013) Chitwan National Park and Its Buffer Zone Management Plan 2013-2017. Kasara, Chitwan

Dhakal M, Karki M, Jnawali SR et al (2014) Status of tigers and Prey in Nepal, Kathmandu. Tech Rep. https://doi.org/10.13140/2.1.3290.2407

Duangchantrasiri S, Umponjan M, Simcharoen S et al (2016) Dynamics of a low-density tiger population in Southeast Asia in the context of improved law enforcement. Conserv Biol 30:639-648. https ://doi.org/10.1111/cobi.12655

Goodrich J, Lynam A, Miquelle D, et al (2015) Panthera tigris. In: IUCN Red List Threat. Species 2015 e.T15955A50659951. https://www.iucnredlist.org/details/15955/0

Gopalaswamy AM, Royle JA, Hines JE, Singh P, Jathanna D, Kumar NS, Karanth KU (2012) Program SPACECAP: software for estimating animal density using spatially explicit capture-recapture models. Methods Ecol Evol 3:1067-1072. https://doi.org/10.1111/j.2041-210X.2012.00241.X

Gotelli NJ (2001) Research frontiers in null model analysis. Glob Ecol Biogeogr 10:337-343. https://doi. org/10.1046/j.1466-822X.2001.00249.x

Gray TNE, Prum S (2012) Leopard density in post-conflict landscape, Cambodia: evidence from spatially explicit capture-recapture. J Wildl Manage 76:163-169. https://doi.org/10.1002/jwmg.230

Grueber CE, Nakagawa S, Laws RJ, Jamieson IG (2011) Multimodel inference in ecology and evolution: challenges and solutions. J Evol Biol 24:699-711. https://doi.org/10.1111/j.1420-9101.2010.02210 .X

Gurung B, Smith JLD, McDougal C et al (2008) Factors associated with human-killing tigers in Chitwan National Park, Nepal. Biol Conserv 141:3069-3078. https://doi.org/10.1016/j.biocon.2008.09.013

Gurung B, Nelson KC, Smith JLD (2009) Impact of grazing restrictions on livestock composition and husbandry practices in Madi Valley, Chitwan National Park, Nepal. Environ Conserv 36:338-347. https://doi.org/10.1017/S0376892910000160

Harihar A, Pandav B, Goyal SP (2011) Responses of leopard Panthera pardus to the recovery of a tiger Panthera tigris population. J Appl Ecol 48:806-814. https://doi.org/10.1111/j.1365-2664.2011.01981.x

Hiby L, Lovell P, Patil N et al (2009) A tiger cannot change its stripes: using a three-dimensional model to match images of living tigers and tiger skins. Biol Lett 5:383-386. https://doi.org/10.1098/ rsbl.2009.0028

Holt RD, Polis GA (1997) A theoretical framework for intraguild predation. Am Nat. https://doi. org/10.1086/286018

Jacobson AP, Gerngross P, Lemeris JR Jr et al (2016) Leopard (Panthera pardus) status, distribution, and the research efforts across its range. PeerJ 4:e1974. https://doi.org/10.7717/peerj.1974

Johnson A, Vongkhamheng C, Hedemark M, Saithongdam T (2006) Effects of human-carnivore conflict on tiger (Panthera tigris) and prey populations in Lao PDR. Anim Conserv 9:421-430. https://doi. org/10.1111/j.1469-1795.2006.00049.x 
Kalle R, Ramesh T, Qureshi Q, Sankar K (2011) Density of tiger and leopard in a tropical deciduous forest of Mudumalai Tiger Reserve, southern India, as estimated using photographic capture-recapture sampling. Acta Theriol (Warsz) 56:335-342. https://doi.org/10.1007/s13364-011-0038-9

Kapfer PM, Streby HM, Gurung B, Simcharoen A, McDougal CC, Smith JL (2011) Fine-scale spatiotemporal variation in tiger Panthera tigris diet: effect of study duration and extent on estimates of tiger diet in Chitwan National Park, Nepal. Wildl Biol 17:277-285

Karanth KU, Chellam R (2009) Carnivore conservation at the crossroads. Oryx 43:1-2. https://doi. org/10.1017/S003060530843106X

Karanth KU, Nicholas JD (1998) Estimation of Tiger Densites in India using photographic captures and recapture. Ecology 79(8):2852-2862. https://doi.org/10.2307/176521

Karanth KU, Sunquist ME (1995) Prey selection by tiger, leopard and dhole in tropical forests. J Anim Ecol 64(4):439-450. https://doi.org/10.2307/5647

Karanth KU, Sunquist ME (2000) Behavioural correlates of predation by tiger (Panthera tigris), leopard (Panthera pardus) and dhole (Cuon alpinus) in Nagarahole, India. J Zool 250:255-265. https://doi. org/10.1111/j.1469-7998.2000.tb01076.x

Karanth KU, Srivathsa A, Vasudev D, Puri M, Parameshwaran R, Kumar NS (2017) Spatio-temporal interactions facilitate large carnivore sympatry across a resource gradient. Proc R Soc B 284:20161860. https:// doi.org/10.1098/rspb.2016.1860

Karki JB, Pandav B, Jnawali SR et al (2015) Estimating the abundance of Nepal's largest population of tigers Panthera tigris. Oryx 49:150-156. https://doi.org/10.1017/S0030605313000471

Kawanishi K, Sunquist ME (2004) Conservation status of tigers in a primary rainforest of Peninsular Malaysia. Biol Conserv 120:333-348. https://doi.org/10.1016/j.biocon.2004.03.005

Kenney J, Allendorf FW, McDougal C, Smith JLD (2014) How much gene flow is needed to avoid inbreeding depression in wild tiger populations? Proc R Soc B Biol Sci. https://doi.org/10.1098/rspb.2013.3337

Kolipaka SS (2018) Can tigers survive in human-dominated landscapes ?. Leiden University, Leiden

Lamichhane BR, Dhakal M, Subedi N, Pokheral CP (2014) Clouded leopard co-exist with other five felids in Chitwan National Park, Nepal. Cat News 61:34-37

Lamichhane BR, Persoon GA, Leirs H et al (2017) Are conflict-causing tigers different? Another perspective for understanding human-tiger conflict in Chitwan National Park, Nepal. Glob Ecol Conserv 11:177-187. https://doi.org/10.1016/j.gecco.2017.06.003

Lamichhane BR, Persoon GA, Leirs H et al (2018a) Spatio-temporal patterns of attacks on human and economic losses from wildlife in Chitwan National Park, Nepal. PLoS ONE. https://doi.org/10.1371/journ al.pone.0195373

Lamichhane BR, Pokheral CP, Poudel S et al (2018b) Rapid recovery of tigers Panthera tigris in Parsa Wildlife Reserve, Nepal. ORYX 52:16-24. https://doi.org/10.1017/S0030605317000886

Lamichhane BR, Persoon GA, Leirs H, Poudel S, Subedi N, Pokheral CP, Bhattarai S, Gotame P, Mishra R, De Iongh HH (2019) Contribution of buffer zone programs to reduce human-wildlife impacts: the case of the Chitwan National Park, Nepal. Hum Ecol 47(1):95-110. https://doi.org/10.1007/s1074 5-019-0054-y

Lehmkuhl JF (1994) A classification of subtropical riverine grassland and forest in Chitwan National Park, Nepal. Vegetation 111:29-43. https://doi.org/10.1007/BF00045575

Linnell JDC, Strand O (2000) Interference interactions, co-existence and conservation of mammalian carnivores. Divers Distrib 6:169-176. https://doi.org/10.1046/j.1472-4642.2000.00069.x

Linnell JDC, Swenson JE, Andersen R (2001) Predators and people: conservation of large carnivores is possible at high human densities if management policy is favourable. Anim Conserv 4:345-349. https://doi. org/10.1017/S1367943001001408

Lovari S, Pokheral CP, Jnawali SR et al (2015) Coexistence of the tiger and the common leopard in a prey-rich area: the role of prey partitioning. J Zool 295:122-131. https://doi.org/10.1111/jzo.12192

McDougal C (1998) Leopard and tiger interactions at Royal Chitwan National park, Nepal. J Bombay Nat Hist Soc 85:609-610

McDougal C, Gurung B, Tamang DB et al (2016) Stability of Tigers in Chitwan Nation Park Nepal. Cat News 64:33-36

Miller JRB, Jhala YV, Jena J (2016) Livestock losses and hotspots of attack from tigers and leopards in Kanha Tiger Reserve, Central India. Reg Environ Chang 16:17-29. https://doi.org/10.1007/s10113-015-0871-5

Mukherjee S, Goyal SP, Chellam R (1994) Refined techniques for the analysis of Asiatic lion Panthera leo persica scats. Acta Theriol (Warsz) 39:425-430. https://doi.org/10.4098/AT.arch.94-50

Nepal S, Spiteri A (2011) Linking livelihoods and conservation: an examination of local residents' perceived linkages between conservation and livelihood benefits around Nepal's Chitwan National Park. Environ Manage 47:727-738. https://doi.org/10.1007/s00267-011-9631-6 
Odden M, Wegge P, Fredriksen T (2010) Do tigers displace leopards? If so, why? Ecol Res 25:875-881. https:// doi.org/10.1007/s11284-010-0723-1

Pokheral CP, Wegge P (2018) Coexisting large carnivores: spatial relationships of tigers and leopards and their prey in a prey-rich area in lowland Nepal. Écoscience 00:1-9. https://doi.org/10.1080/11956 860.2018 .1491512

QGIS Development Team (2016) QGIS Version 2.7. In: Qgis. http://www.qgis.org/en/site/

R Core Team (2017) R Development Core Team. R A Lang. Environ Stat Comput 55:275-286

Rayan DM, Linkie M (2016) Managing conservation flagship species in competition: tiger, leopard and dhole in Malaysia. Biol Conserv 204:360-366

Ridout MS, Linkie M (2009) Estimating overlap of daily activity patterns from camera trap data. J Agric Biol Environ Stat 14:322-337. https://doi.org/10.1198/jabes.2009.08038

Ripple WJ, Estes JA, Beschta RL, Wilmers CC, Ritchie EG, Hebblewhite M, Berger J, Elmhagen B, Letnic M, Nelson MP, Schmitz OJ, Smith DW, Wallach AD, Wirsing AJ (2014) Status and ecological effects of the world's largest carnivores. Science 343(6167):1241484. https://doi.org/10.1126/science.12414 84

Rosenzweig ML (1966) Community structure in sympatric carnivora. J Mamm 47:602-612. https://doi. org/10.2307/1377891

Schmitz OJ, Hambäck PA, Beckerman AP (2000) Trophic cascades in terrestrial systems: a review of the effects of carnivore removals on plants. Am Nat 155(2):141-153. https://doi.org/10.1086/303311

Seidensticker J (1976) On the ecological separation between tigers and leopards. Biotropica 8:225-234. https:// doi.org/10.2307/2989714

Shrestha MK (2004) Relative ungulate abundance in a fragmented landscape: implications for tiger conservation. University of Minnesota, Minneapolis

Simcharoen A, Savini T, Gale GA et al (2014) Female tiger Panthera tigris home range size and prey abundance: important metrics for management. Oryx 48:370-377. https://doi.org/10.1017/S00306053120014 08

Simcharoen A, Simcharoen S, Duangchantrasiri S et al (2018) Tiger and leopard diets in western Thailand: evidence for overlap and potential consequences. Food Webs 15:e00085. https://doi.org/10.1016/j.foowe b.2018.e00085

Smith JLD (1993) The role of dispersal in structuring the Chitwan tiger population. Behaviour 124:165-195. https://doi.org/10.1163/156853993X00560

Smith JLD, McDougal C (1991) The contribution of variance in lifetime reproduction to effective population size in tigers. Conserv Biol 5:484-490. https://doi.org/10.1111/j.1523-1739.1991.tb00355.x

Smith JLD, McDougal C, Sunquist ME (1989) Female land tenure system in tigers. In: Tilson RL, Seal US (eds) Tigers of the World: the biology, biopolitics management and conservation of an endangered species. Noyes, Park Ridge, pp 97-109

Srivathsa A, Parameshwaran R, Sharma S, Karanth KU (2015) Estimating population sizes of leopard cats in the Western Ghats using camera surveys. J Mamm 96:742-750. https://doi.org/10.1093/jmammal/gyv079

Stein AB, Athreya V, Gerngross P, et al (2018) Panthera pardus. IUCN Red List Threat. Species 2016 e.T15954A102421779

Subedi N, Lamichhane BR, Amin R et al (2017) Demography and viability of the largest population of greater one-horned rhinoceros in Nepal. Glob Ecol Conserv 12:241-252. https://doi.org/10.1016/j.gecco .2017 .11 .008

Sunquist ME (1981) The Social Organization of Tigers (Panthera tigris) in Royal Chitawan National Park, Nepal. Smithson Contrib Zool. https://doi.org/10.5479/si.00810282.336

Thapa TB (2011) Habitat suitability evaluation for leopard (Panthera pardus) using remote sensing and GIS in and around Chitwan National Park. Saurastra University, Nepal

Thapa K, Kelly MJ (2017) Density and carrying capacity in the forgotten tigerland: tigers in the understudied Nepalese Churia. Integr Zool 12:211-227. https://doi.org/10.1111/1749-4877.12240

Thapa K, Shrestha R, Karki J et al (2014) Leopard Panthera pardus fusca density in the seasonally dry, subtropical forest in the Bhabhar of Terai Arc, Nepal. Adv Ecol 2014:1-12. https://doi.org/10.1155/2014/286949

Turner A, Anton M (1997) The big cats and their fossil relatives: an illustrated guide to their evolution and natural history. Columbia University Press, New York

UNESCO (2003) UNESCO - IUCN Enhancing Our Heritage Project: Monitoring and Managing for Success in Natural World Heritage Sites Initial Management Effectiveness Evaluation Report. Royal Chitwan National Park, Paris

Upadhyaya SK, Musters CJM, Lamichhane BR et al (2018) An insight into the diet and prey preference of tigers in Bardia National Park, Nepal. Trop Conserv Sci 11:1940082918799476. https://doi.org/10.1177/19400 82918799476 
Walston J, Robinson JG, Bennett EL et al (2010) Bringing the tiger back from the brink-the six percent solution. PLoS Biol 8:e100048. https://doi.org/10.1371/journal.pbio.1000485

Wang SW, Macdonald DW (2009) The use of camera traps for estimating tiger and leopard populations in the high altitude mountains of Bhutan. Biol Conserv 142:606-613. https://doi.org/10.1016/j.bioco n.2008.11.023

Weber W, Rabinowitz A (1996) A global perspective on large carnivore conservation. Conserv Biol 10:10461054. https://doi.org/10.1046/j.1523-1739.1996.10041046.x

Wegge P, Yadav SK, Lamichhane BR (2018) Are corridors good for tigers Panthera tigris but bad for people? An assessment of the Khata corridor in lowland Nepal. Oryx 52:35-45. https://doi.org/10.1017/S0030 605316000661

Wikramanayake E, McKnight M, Dinerstein E et al (2004) Designing a conservation landscape for tigers in human-dominated environments. Conserv Biol 18:839-844. https://doi.org/10.111 $1 /$ j.1523-1739.2004.00145.x

Zuur AF, Ieno EN, Walker NJ et al (2009) Mixed effects models and extensions in ecology with R. Stat Biol Heal. https://doi.org/10.1007/978-0-387-87458-6

Publisher's Note Springer Nature remains neutral with regard to jurisdictional claims in published maps and institutional affiliations.

\section{Affiliations}

\section{Babu Ram Lamichhane ${ }^{1,2,3}$ (D) $\cdot$ Herwig Leirs ${ }^{2} \cdot$ Gerard A. Persoon ${ }^{1} \cdot$ Naresh Subedi $^{3}$. Maheshwar Dhakal ${ }^{4}$. Bishwa Nath Oli ${ }^{4}$. Simon Reynaert ${ }^{2} \cdot$ Vincent Sluydts $^{2}$. Chiranjibi Prasad Pokheral ${ }^{3} \cdot$ Laxman Prasad Poudyal $^{6}$. Sabita Malla ${ }^{7}$. Hans H. de longh ${ }^{2,5}$}

1 Faculty of Social and Behavioural Sciences, Institute of Cultural Anthropology and Development Sociology, Leiden University, 2333 AK Leiden, The Netherlands

2 Evolutionary Ecology Group, Faculty of Sciences, University of Antwerp, Campus Drie Eiken, 2610 Antwerp, Belgium

3 National Trust for Nature Conservation (NTNC), Khumaltar, POB 3712, Lalitpur, Nepal

4 Ministry of Forests and Environment, Singhadurbar, Kathmandu, Nepal

5 Faculty of Sciences, Institute of Environmental Sciences (CML), Leiden University, 2300 RA Leiden, The Netherlands

6 Department of National Parks and Wildlife Conservation, Babarmahal, Kathmandu, Nepal

7 WWF Nepal, Baluwatar, Kathmandu, Nepal 